\title{
PERTUMBUHAN EKONOMI DAN KETIMPANGAN PENDAPATAN ANTAR KABUPATEN DI KALIMANTAN TIMUR
}

\author{
Tutik Yuliani $^{\bowtie}$ \\ ${ }^{1}$ Universitas Balikpapan, Indonesia \\ Permalink/DOI: http://dx.doi.org/10.15294/jejak.v7i1. \\ Received : 1 November 2014; Accepted: 3 Desember 2015; Published: March 2015

\begin{abstract}
This study aims to find out the development and income inequality inter regency in East Kalimantan and prove whether the inverted U hypothesis applied in the East Kalimantan. To find out how much income inequality, the writer used Williamson and Theil's Entropy Index. Based on Williamson index, it indicates that there is income inequality inter regency in East Kalimantan during 2010 to 2012 , at 0.69 in 2010 to 0.72 in 2012. Whereas Entropy Theil calculation shows that on average during 2010 to 2012, there was income inequality by 17.45. Meanwhile, Kuznets analysis shows that Kuznets law applied in East Kalimantan during 2010 to 2012.
\end{abstract}

Keywords: economic growth, income gap, inverted U curve

\begin{abstract}
Abstrak
Penelitian ini bertujuan untuk mengetahui ketimpangan pembangunan dan pendapatan antar Kabupaten di Kalimantan Timur serta membuktikan apakah Hipotesis U terbalik berlaku di Propinsi Kalimantan Timur. Untuk mengetahui seberapa besar ketimpangan pendapatan digunakan Indeks Williamson dan Indeks Entropi Theil,.Berdasarkan indeks Wiliamson menunjukkan bahwa selama tahun 2010 sampai dengan 2012 terdapat ketimpangan pembanguan antar kabupaten di Kalimantan Timur sebesar o.69 di tahun 2010 menjadi 0.72 di tahun 2012. Sedangkan dari hitungan Entropi Theil menunjukkan bahwa rata-rata selama tahun 2010 sampai dengan 2012 terdapat ketimpangan pendapatan sebesar 17.45. Setelah dilakukan analisis Kuznets menunjukkan bahwa di Kalimantan Timur selama tahun 2010 sampai dengan 2012 berlaku hukum Kuznets.
\end{abstract}

Kata Kunci: pertumbuhan ekonomi, ketimpangan pendapatan, hipotesis U terbalik

How to Cite: . (2014). judul. JEJAK Journal of Economics and Policy, 8 (1): 1-88 doi: 10.15294jejak.v7i1.

(C) 2015 Semarang State University. All rights reserved 


\section{PENDAHULUAN}

Pembangunan ekonomi pada hakekatnya bertujuan untuk meningkatkan kesejahteraan masyarakat, dalam rangka meningkatkan kesejahteraan masyarakat maka diperlukan pertumbuhan ekonomi yang meningkat dan distribusi pendapatan yang lebih merata. Peningkatan dan pertumbuhan perekonomian daerah akan membawa pengaruh terhadap peningkatan kesejahteraan rakyat di daerah (Raswita \& Made, 2013). Hubungan antara ketimpangan dan pertumbuhan ekonomi adalah topik ekonomi pembangunan dan isu pemerintahan yang menarik di negara berkembang. Hal ini dikarenakan adanya keterkaitan yang erat antara kedua variabel ini dalam kehidupan masyarakat dan stabilitas sosial (Das et al, 2014 dan Dewanto et al, 2014).

Ketimpangan pembangunan antara daerah yang satu dengan daerah yang lainnya berdampak pada keseimbangan perputaran kegiatan ekonomi yang berpengaruh pada ketimpangan kemakmuran antar daerah yang bersangkutan. Tambunan (2001) menyatakan terkonsentrasinya kegiatan ekonomi pada suatu daerah tertentu secara langsung berdampak pada ketimpangan pandapatan antar daerah sehingga tercipta kondisi dimana daerah yang menjadi pusat konsentrasi kegiatan ekonomi akan lebih mampu memberikan pendapatan yang lebih tinggi kepada masyarakatnya sehingga masyarakatnya relatif lebih makmur, sementara disisi lain daerah yang bukan merupakan pusat kegiatan ekonomi hanya mampu memberikan pendapatan yang rendah sehingga berakibat relatif rendah pula kemakmuran masyarakatnya.

Oleh karena itu upaya mewujudkan pemerataan ketimpangan pembangunan antar daerah menjadi sangat penting agar tujuan dari pembangunan yakni peningkatan ketersediaan serta perluasan distribusi barang kebutuhan pokok, peningkatan standar hidup masyarakat dapat terwujud secara bersama-sama baik pada tingkat regional maupun nasional. Disparitas secara ekonomi diartikan sebagai adanya perbe-
Timur

daan yang mencolok antara golongan orang kaya dan orang miskin dalam hal distribusi pendapatan, distribusi kesejahteraan, latar belakang pendidikan, jenis pekerjaan, tingkat kepuasan dan kebahagiaan hidup (Adrei dan Craciun, 2014).

Kesenjangan pembangunan ekonomi antar kabupaten/kota di Propinsi Kalimantan Timur berdasarkan data PDRB antar kabupaten/Kota di Propinsi Kalimantan Timur dapat dilihat dari nilai PDRB antar kabupaten/kota berbeda-beda dan selama tiga tahun terakhir nilai PDRB tiap-tiap kabupaten/kota mengalami peningkatan. Pada Tahun 2012, Kutai Timur memiliki nilai PDRB tertinggi kemudian diikuti oleh,

Kutai Kartanegara, Samarinda, Balikpapan, Paser, Kutai Barat, Berau, Bontang, Tarakan, Penajam Paser Utara, Nunukan, Bulungan, Malinau, Tana Tidung, dimana Tana Tidung memiliki nilai PDRB terendah.

Selama tiga tahun terakhir yaitu dari tahun 2010 sampai dengan 2012 laju pertumbuhan ekonomi di tiap Kabupaten/ Kota mengalami naik turun yang berbeda antar Kabupaten/ Kota di Propinsi Kalimantan Timur. Misalnya pada tahun 2012 nilai laju PDRB tertinggi adalah di Kutai Kartanegara, Kutai Timur, Malinau, Bulungan, Balikpapan, Paser, Berau, Nunukan, Kutai Barat, Tarakan, Bontang, Tana Tidung, Penajam Paser Utara dan laju pertumbuhan ekonomi terendah yaitu di Samarinda. Perbedaan tingkat pembangunan yang ditunjukkan dengan perbedaan nilai PDRB dan laju PDRB antar daerah akan membawa dampak perbedaan tingkat kesejahteraan antar daerah yang pada akhirnya menyebabkan ketimpangan regional antar daerah semakin lebar serta dapat menghambat pembangunan ekonomi daerah.

Menurut Adam Smith (ahli ekonomi klasik), ada dua aspek utama pertumbuhan ekonomi yaitu (1) pertumbuhan output (GDP) total dan (2) pertumbuhan penduduk. Kedua aspek tersebut berkaitan satu sama lainnya. Berkaitan dengan pertumbuhan output total, Smith melihat sistem produksi suatu negara terdiri dari tiga unsur pokok yaitu sumber daya alam yang tersedia, sumber daya manusiawi (jumlah 
penduduk) dan stok barang kapital yang ada. Sumber- sumber alam yang tersedia merupakan wadah yang paling mendasar dari kegiatan produksi suatu masyarakat. Jumlah sumber-sumber alam yang tersedia merupakan batas maksimum bagi pertumbuhan perekonomian tersebut. Artinya, selama sumber-sumber ini belum sepenuhnya dimanfaatkan, yang memegang peranan dalam proses produksi adalah dua unsur produksi yang lain, yaitu jumlah penduduk dan stok kapital yang ada.

Menurut Kuznets dalam Todaro (2004), pertumbuhan ekonomi (economic growth) adalah kenaikan kapasitas dalam jangka panjang dari negara yang bersangkutan untuk menyediakan berbagai barang ekonomi kepada penduduknya. Kenaikan kapasitas di tentukan oleh adanya kemajuan atau penyesuaian-penyesuaian teknologi, institusi (kelembagaan), dan ideologis terhadap berbagai tuntutan keadaan yang ada.

Selain itu, Todaro (2003) menyatakan ada 3 faktor dalam pertumbuhan ekonomi di setiap negara yakni; (1) Akumulasi modal (capital accumulation), meliputi semua jenis investasi baru yang ditanamkan pada pabrik baru, tanah, peralatan fisik dan pembagian sumber daya manusia juga dapat meningkatkan kualitasnya, sehingga pada akhirnya akan membawa dampak positif yang sama terhadap angka produksi. Akumulasi modal terjadi apabila sebagian dari pendapatan diinvestasikan kembali dengan tujuan memperbesar output atau pendapatan pada masa yang akan datang; (2) Pertumbuhan penduduk (growth in population) maksudnya adalah dengan pertumbuhan penduduk diikuti oleh pertumbuhan tenaga kerja sebagai salah satu faktor positif yang memacu pertumbuhan ekonomi. Ini berarti dengan pertambahan penduduk akan menambah jumlah produktifitas. Pertumbuhan penduduk yang lebih besar akan menyebabkan pertumbuhan pasar domestik menjadi lebih besar, namun positif atau negatifnya pertumbuhan penduduk dalam pembangunan ekonomi sepenuhnya tergantung pada kemampuan sistem perekonomian tersebut untuk menyerap setiap tambahan angkatan kerja; (3) Kemajuan teknologi (technologi- cal progress) merupakan sumber pertumbuhan ekonomi yang paling penting, karena dengan kemajuan teknologi akan ditemukan cara baru ataupun teknologi baru untuk menggantikan cara-cara lama sehingga dapat meningkatkan pertumbuhan ekonomi dengan cepat.

Menurut Adelman dan Morris (1973) secara umum yang menyebabkan ketidakmerataan distribusi pendapatan di negara sedang berkembang adalah pertambahan penduduk yang tinggi yang mengakibatkan menurunnya pendapatan perkapita, inflasi yang dikarenakan pendapatan uang bertambah tetapi tidak diikuti secara proporsional dengan pertambahan produksi barang-barang, ketidakmerataan pembangunan antar daerah, capital intensif sehingga persentase pendapatan modal dari harta tambahan lebih besar dibandingkan persentase pendapatan yang berasal dari kerja sehingga pengangguran bertambah, rendahnya mobilitas sosial, kebijakan industri substitusi impor yang berakibat pada peningkatan harga barang hasil industri, memburuknya nilai tukar bagi negara sedang berkembang dengan negara maju, dan hancurnya industriindustri kerajinan rakyat, dan lain-lain (Arsyad, 2004).

Kuncoro (2004) melakukan penelitian tentang pertumbuhan ekonomi dan ketimpangan antar kecamatan : kasus kabupaten Banyumas, Jawa Tengah. Hasil penelitian menunjukkan bahwa (1) berdasarkan tipologi daerah menurut pertumbuhan dan pendapatan per kapita, daerah/kecamatan di Kabupaten Banyumas dapat diklasifikasikan menjadi empat kelompok, yaitu daerah cepat maju dan cepat tumbuh, daerah yang maju tertekan, daerah yang berkembang cepat, dan daerah tertinggal, (2) Pada periode pengamatan 1993-2000, terjadi kecenderungan peningkatan ketimpangan, baik dianalisis dengan indeks Williamson maupun dengan indeks entropi theil. Ketimpangan ini salah satu disebabkan oleh konsentrasi aktivitas ekonomi secara spasial., (3) Hipotesis Kuznets mengenai ketimpangan yang berbentuk U-terbalik

Kuznets (1995) menemukan bahwa ada hubungan antara pertumbuhan eko- 
Tutik Yuliani, Pertumbuhan Ekonomi dan Ketimpangan Pendapatan Antar Kabupaten di Kalimantan Timur

nomi dan perbedaan pendapatan berupa kurva berbentuk "U-terbalik" yaitu proses pertumbuhan melalui perluasan sektor modern yang pada awalnya mengakibatkan peningkatan perbedaan pendapatan di antara rumah tangga, kemudian mencapai tingkat pendapatan rata-rata tertentu dan akhirnya mulai menurun. Selain faktor-faktor sosial, ekonomi dan politik ada dua faktor penting yang mempengaruhi pola tersebut, yaitu terpusatnya modal pada kelompok pandapatan tinggi dan pergeseran penduduk dari sektor pertanian tradisional menuju sektor industri modern (Sutarno, 2002).

Bahasan mengenai hubungan antara ketimpangan dan pertumbuhan ekonomi mulai mengemuka ketika ekonom Simon Kuznets mengemukakan hipotesis $\mathrm{U}$ terbalik (Galbraith dan Kum, 2012). Kuznets mengatakan bahwa mula-mula ketika pembangunan di mulai distribusi pendapatan tidak merata, namun setelah mencapai suatu tingkat pembangunan tertentu distribusi pendapatan makin merata (Kuncoro, 2004). Seolah-olah dalam jangka pendek ada korelasi positif antara pertumbuhan ekonomi dan ketimpangan distribusi pendapatan, artinya pertumbuhan ekonomi akan diikuti dengan meningkatnya ketimpangan distribusi pendapatan. Namun dalam jangka panjang hubungan keduanya menjadi korelasi negatif, artinya peningkatan pendapatan akan diikuti dengan penurunan ketimpangan distribusi pendapatan (Todaro, 2004).

Kuznets mengatakan bahwa pada tahap awal pertumbuhan ekonomi, distribusi pendapatan cenderung memburuk, namun pada tahap selanjutnya, distribusi pendapatannya akan membaik. Hipotesis Kuznets dapat dibuktikan dengan membuat grafik antara pertumbuhan PDRB dan indeks ketimpangan (Kuncoro, 2004).

\section{METODE PENELITIAN}

Jenis Penelitian ini adalah kuantitaif. Jenis data yang digunakan adalah data sekunder yang didapat secara langsung dari Badan Pusat Statistik (BPS), yang meliputi PDRB per kapita di Propinsi Kalimantan Timur tahun 2010 sampai dengan 2012, PDRB Per Kapita tiap kabupaten atas dasar harga konstan di Kalimantan Timur dari tahun 2010 sampai dengan 2012, Pertumbuhan Ekonomi kabupaten di Propinsi Kalimantan Timur dari tahun 2010 sampai dengan 2012, Perkembangan jumlah penduduk tiap kabupaten di Kalimantan Timur dari tahun 2010 sampai dengan 2012. Teknik analisis data menggunakan Indeks Willianson, Indeks Etropi Theil, Hipotesis Kuznets.

Ketimpangan pembangunan (kesenjangan) antar kabupaten/kota di Propinsi Kalimantan Timur akan dianalisa dengan menggunakan Indeks Ketimpangan Williamson dengan formula sebagai berikut (syafrizal, 2008):

$$
I W=\frac{\sqrt{\sum\left(Y_{i}-Y\right)^{2} f_{i} / n}}{Y}
$$

Keterangan :

Yi : PDRB per kapita di kabupaten/kota i, Y : PDRB per kapita rata-rata Kalimantan Timur,

$f_{i}$ : Jumlah penduduk di Kabupaten/kota i

$n$ : merupakan Jumlah penduduk Propinsi Kalimantan Timur.

Angka indeks ketimpangan williamson yang semakin kecil atau mendekati nol menunjukkan ketimpangan yang semakin kecil atau pembangunan antar wilayah semakin merata dan bila semakin jauh dari titik nol (mendekati satu) menunjukkan ketimpangan yang semakin melebar. Analisa ketimpangan pendapatan regional antar wilayah di kabupaten/kota juga ddapat dihitung menggunakan Indeks Entropi Theil (Kuncoro : 2004) dengan rumus sebagai berikut :

$\mathbf{I}(\mathbf{y})=\sum\left(\mathbf{y}_{\mathbf{j}} / \mathbf{Y}\right) \times \log \left[\left(\mathbf{y}_{\mathrm{i}} / \mathbf{Y}\right) /\left(\mathbf{x}_{\mathbf{j}} / \mathbf{X}\right)\right]_{(2)}$

I (y) : Indeks Entropi Theil

$y_{j} \quad$ : PDRB per kapita kabupaten/kota,

Y : Rata-rata PDRB per kapita

Propinsi Kalimantan Timur,

$\mathrm{x}_{\mathrm{i}} \quad$ : Jumlah penduduk kabupaten/

kota

X : Jumlah penduduk Propinsi

Kalimantan Timur 
Indeks entropi theil yang semakin besar menunjukkan ketimpangan yang semakin besar pula, demikian pula sebaliknya bila indeksnya semakin kecil, maka ketimpangan akan semakin rendah/ kecil atau dengan kata lain semakin merata. Indeks ketimpangan entropi theil tidak memiliki batas atas atau batas bawah, hanya apabila semakin besar nilainya, maka semakin timpang dan semakin kecil nilainya maka semakin merata.

Selanjutnya analisis yang digunakan adalah hipotesis Kuznets yang lebih dikenal dengan kurva U terbalik dibuktikan dengan melihat hubungan antara pertumbuhan ekonomi dengan Indeks Williamson. Persyaratan yang harus dipenuhi agar hubungan antara pertumbuhan ekonomi dengan pertumbuhan ekonomi kuadrat Propinsi Kalimantan Timur sebagai variabel independen memiliki bentuk kurva $U$ terbalik adalah $\beta$ bernilai negatif. Dari hasil regresi kuadratik (quadratic regression analysis) diperoleh persamaan regresi.

Selain melakukan analisis tentang pembuktian Kurva Kuznetz, akan dilakukan pula analisis korelasi pearson untuk melihat hubungan antara variabel pertumbuhan ekonomi dan ketimpangan pembangunan (indeks Williamson). Rumus untuk menghitung korelasi pearson adalah sebagai berikut : (Subagyo dan Djarwanto, 2005:288).

Nilai $r$ dapat bervariasi dari -1 melalui o hingga +1 . Bila $\mathrm{r}=\mathrm{o}$ atau mendekati $\mathrm{o}$ maka hubungan antara dua variabel sangat lemah atau tidak ada hubungan sama sekali. Bila nilai $\mathrm{r}=+1$ atau mendekati 1 maka hubungan antara kedua variabel dikatakan positif dan sangat kuat. Nilai korelasi yang positif $(+)$ berarti arah hubungan variabel yang satu dengan yang lain adalah satu arah, dengan kata lain apabila nilai variabel yang satu naik maka nilai variabel yang lain juga ikut naik. Jika $\mathrm{r}=-1$ atau mendekati -1 maka korelasinya sangat kuat tetapi negativ. r bertanda negativ (-) artinya hubungan antara dua variabel berlawanan, dengan kata lain yaitu apabila nilai variabel yang satu turun maka nilai variabel yang lain naik, atau sebaliknya. Untuk memastikan apakah Ho atau Ha yang diterima maka digunakan uji dua arah dengan tingkat signifikan o.01. Keputusan Ho diterima apabila - $\mathrm{t}(\alpha / 2)<\mathrm{t}$ uji $<+1(\alpha / 2)$.

\section{HASIL DAN PEMBAHASAN}

Untuk mengetahu ketimpangan pembangunan dibeberapa wilayah sudah dilakukan oleh beberapa peneliti. Ada beberapa alat analisis yang dapat digunakan untuk menentukan kesenjangan pembangunan ekonomi dan ketimpangan pendapatan, antara lain dengan menggunakan Indeks Williamson (Williamson, 1965 dan Sjafrizal, 2008), Koefisien Gini (Arsyad, 2004), Indeks Kuznets, Indeks Oshima, dan Indeks Entropi Theil (Ying, 200o dan Akita, 200o) . Pada penelitian ini akan jelaskan tentang hasil analisis ketimpangan pembangunan yang akan dianalisis dengan menggunakan Indeks Williamson dan hasil analisis ketimpangan pendapatan yang akan dianalisis dengan menggunakan Indeks Entropi Theil.

Besar kecilnya ketimpangan PDRB per kapita antar Kabupaten/Kota memberikan gambaran perkembangan pembangunan di Propinsi Kalimantan Timur. Keberhasilan ekonomi kabupaten/kota di Propinsi Kalimantan Timur dalam mencapai pertumbuhan ekonomi tinggi dalam beberapa periode ternyata menghadapi permasalahan kesenjangan ekonomi antar Kabupaten/ Kota.

Pertumbuhan ekonomi merupakan kunci untuk mengatasi masalah kemiskinan, menurunkan tingkat pertumbuhan ekonomi, melindungi lingkungan dan memperkuat tatanan sipil. Pertumbuhan ekonomi

$r_{x y}=\frac{n \sum_{i=1}^{n} X_{i} Y_{i}-\left(\sum_{i=1}^{n} X_{i}\right)\left(\sum_{i=1}^{n} Y_{i}\right)}{\sqrt{\left[n \sum_{i=1}^{n} X_{i}^{2}-\left(\sum_{i=1}^{n} X_{i}\right)^{2}\right]} \sqrt{n \sum_{i=1}^{n} Y_{i}^{2}-\left(\sum_{i=1}^{n} Y_{i}\right)^{2}}}$

Keterangan $r_{x y}$ adalah Koefisien Korelasi, $\mathrm{X}_{\mathrm{i}}$ merupakan Indeks Williamson, $\mathrm{Y}_{\mathrm{i}}$ Pertumbuhan Ekonomi, dan $\mathrm{n}$ adalah Jumlah Observasi 
Tutik Yuliani, Pertumbuhan Ekonomi dan Ketimpangan Pendapatan Antar Kabupaten di Kalimantan Timur

diukur dari pertumbuhan PDRB suatu daerah. Semakin tinggi PDRB menunjukkan semakin tinggi output barang dan jasa yang dihasilkan. Tingkat kesejahteraan masyarakat dari sisi ekonomi dapat diukur dari seberapa besar PDRB perkapita yang diterima. Namun demikian, tingginya PDRB perkapita yang diterima tersebut belum mampu menggambar kondisi kesejahteraan masyarakat yang sebenarnya. Mungkin saja terjadi nilai PDRB per kapita tinggi namun sebagian besar PDRB perkapita tersebut dinikmati oleh sebagian kecil masyarakat (Tambunan, 2001).

Besar kecilnya ketimpangan PDRB perkapita antar kabupaten/kota memberikan gambaran tentang kondisi perkembangan pembangunan di wilayah Kalimantan Timur. Gambaran tentang perkembangan pembangunan daerah di Propinsi Kalimantan Timur dapat dilihat dari pemerataan PDRB perkapita antar kabupaten/kota yang dianalisis dengan menggunakan indeks Williamson. Formula indeks Williamson menggunakan PDRB perkapita dan jumlah penduduk. Nilai indeks Williamson diperoleh antara nol dan satu $(0<$ IW $<1)$. Angka indeks Williamson yang semakin kecil atau mendekati nol menunjukkan ketimpangan yang semakin kecil atau dengan kata lain makin merata, dan apabila semakin jauh dari nol menunjukkan ketimpangan semakin melebar (Kuncoro, 2004). Dalam penelitian ini dipilih menggunakan Indeks Williamson, karena berbeda dengan yang

lainnya yang hanya menyajikan nilai tunggal pada satu titik tertentu dan melihat kecenderungan pola kesenjangan pembangunan wilayah di Propinsi Kalimantan Timur pada periode 2010-2012. Perkembangan ketimpangan pembangunan antar kabupaten/ kota di Propinsi Kalimantan Timur dapat juga dilihat sebagai berikut :

Dari Gambar 1, Indeks Willianson Kabupaten/Kota di Propinsi Kalimantan Timur. menunjukkan bahwa selama tiga tahun terakhir dari tahun 2010 sampai dengn tahun 2012 hasil indeks williamson terus mengalami peningkatan yaitu o,69 ditahun 2010 meningkat menjadi 0,72 ditahun 2012. Peningkatan ketimpangan pembangunan antar Kabupaten/ Kota di Propinsi Kalimantan Timur salah satunya disebabkan oleh ketidaklancaran proses perdagangan dan mobilitas faktor produksi antar daerah merupakan salah satu penyebab terjadinya ketimpangan wilayah. Karena itu, kebijakan dan upaya yang dapat dilakukan untuk mengurangi ketimpangan pembangunan adalah dengan memperlancar mobilitas barang dan faktor produksi antar daerah. Upaya untuk mendorong kelancaran mobilitas barang dan faktor produksi antar daerah dapat dilakukan melalui penyebaran pembangunan prasarana dan sarana perhubungan keseluruh pelosok wilayah. Prasarana perhubungan yang dimaksudkan disini adalah fasilitas jalan, terminal, pelabuhan laut serta bandara udara guna mendorong proses perdagangan antar daerah (Syafrizal, 2008).

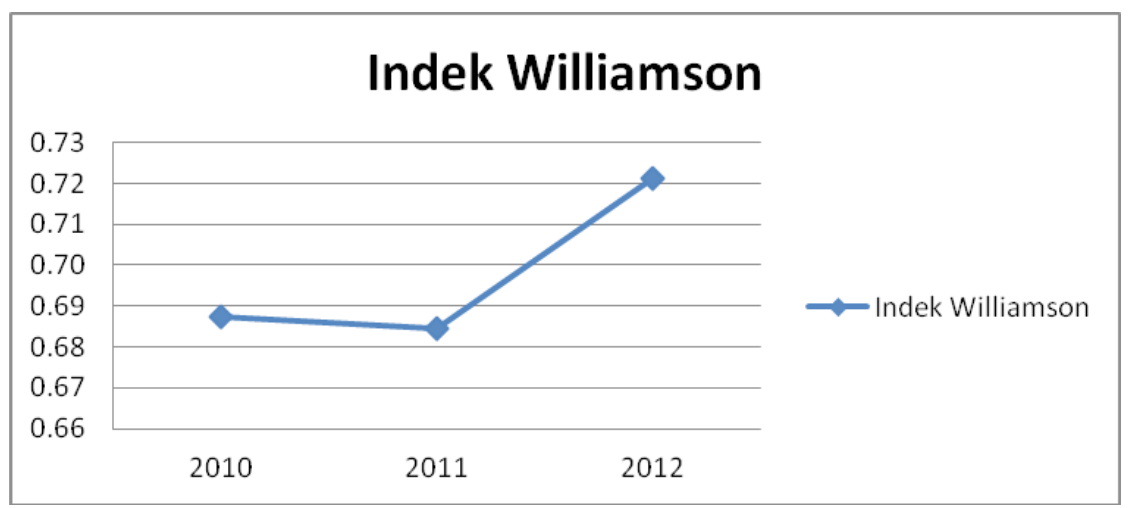

Sumber : Data Sekunder (diolah)

Gambar 1. Indeks Williamson Kabupaten/kota di Propinsi Kalimantan TimurTahun 20102012 
Serta terdapatnya penduduk transmigran yang datang ke Propinsi Kalimantan Timur

Kesenjangan pembangunan ekonomi di Propinsi Kalimantan Timur yang dihitung dengan menggunakan Indeks Williamson menunjukkan bahwa nilai indeks williamson dari tahun 2010-2012 mengalami peningkatan. Nilai indeks williamson yang mengalami peningkatan ini nilainya mendekati nol berarti distribusi pembangunan ekonomi antar Kabupaten/ Kota semakin merata.

Ketimpangan pendapatan antar $\mathrm{Ka}-$ bupaten/ Kota di Propinsi Kalimantan Timur akan dianalisis dengan menggunakan indeks Entropi Theil, dimana dari hasil perhitungan dapat diketahui terjadi atau tidak ketimpangan pendapatan antar Kabupaten/ Kota di Propinsi Kalimantan Timur.

Perkembangan Ketimpangan Pendapatan Di Propinsi Kalimantan Timur Tahun 20102012

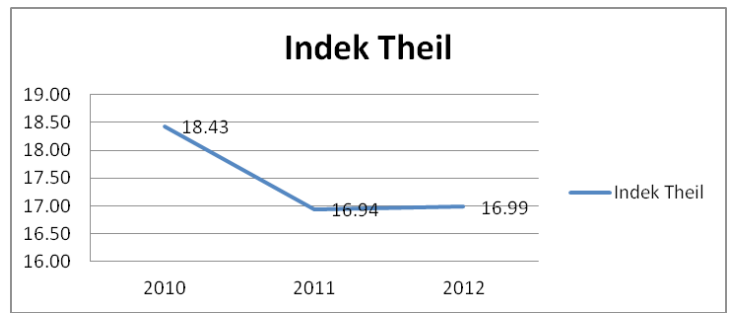

Sumber : Data primer (diolah)

Propinsi Kalimantan Timur memiliki sumber daya alam yang melimpah serta sebagai daerah otonomi sehingga kepentingan pemerintahan menjadi tanggung jawab pemerintah daerah. Hal ini menyebabkan pemerintah daerah dapat mengambil kebijakan-kebijakan yang disesuaikan dengan potensi serta kondisi di daerah, sehingga dapat meningkatkan kondisi perekonomian didaerah yang ditunjukkan pula dengan berkurangnya ketimpangan pendapatan atau semakin meratanya distribusi pendapatan antar penduduk .

Kesenjangan pendapatan perkapita yang dihitung dengan menggunakan Indeks Entropi Theil menunjukkan bahwa nilai Indeks Entropi Theil semakin kecil dari tahun 2010-2012. Apabila nilai indeks yang menurun semakin mendekati nol berarti distri- busi pendapatan perkapita menurut Kabupaten/ Kota di Propinsi Kalimantan Timur mulai merata. Namun, nilai indeks masih berada diatas 0,35 berarti kesenjangan pendapatan perkapita antar Kabupaten/ Kota di Propinsi Kalimantan Timur menurt indikator yang ditetapkan oleh Bank Dunia masih belum menunjukkan tingkat kemerataan yang baik

Apabila dilihat dari gambar-gambar yang ditampilkan sebelumnya, didapat hasil kecenderungan peningkatan ketimpangan dan kemudian mengalami penurunan ketimpangan , tetapi belum membuktikan apakah hipotesis Kuznets berlaku atau tidak di Propinsi Kalimantan Timur artinya pada tahap awal pertumbuhan, distribusi pendapatan cenderung memburuk dan ketimpangan akan meningkat, kemudian pada tahap berikutnya ketimpangan tersebut akan mengalami penurunan dan pemerataan PDRB perkapita akan di capai (Todaro, 2004)..

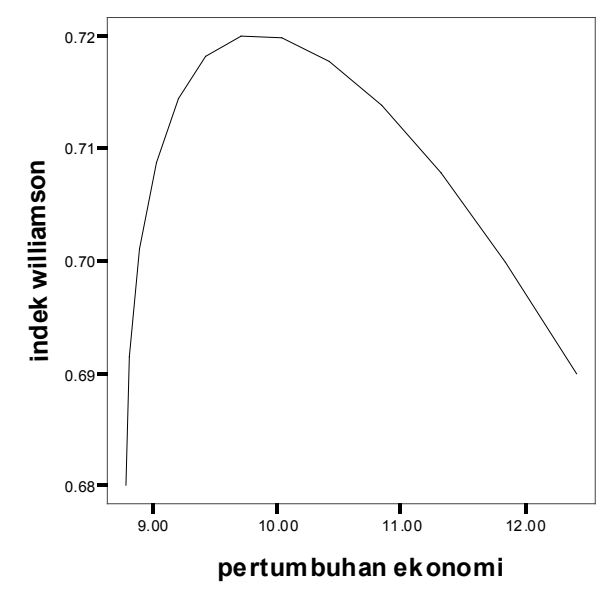

Sumber: Data primer diolah

Gambar 2. Hubungan Indeks Williamson dan Pertumbuhan Ekonomi di Propinsi Kalimantan Timur Tahun 2010-2012

Gambar 2 menunjukkan bahwa Hipotesis Kuznets dibuktikan dengan membuat grafik antara pertumbuhan ekonomi dan indeks ketimpangan Williamson, dengan menjadikan pertumbuhan ekonomi sebagai variabel independen dan indeks ketimpangan williamson sebagai variabel dependenUntuk mengetahui bagaimana 
hubungan antara pertumbuhan ekonomi dengan indeks ketimpangan (indeks williamson) digunakan analisis korelasi person. Berikut disajikan analisis tabel koefisien korelasi pearson.

Tabel 1 Korelasi Pearson antara Pertumbuhan Ekonomi dengan Indeks Williamson

\begin{tabular}{lcc}
\hline Korelasi & \multicolumn{2}{c}{$\begin{array}{l}\text { Pertumbuhan } \\
\text { Ekonomi }\end{array}$} \\
\hline $\begin{array}{l}\text { Indeks } \\
\text { Williamson }\end{array}$ & $-0,333$ & 0.979 \\
\hline
\end{tabular}

Sumber: data diolah

Nilai korelasi positif menunjukkan bahwa arah hubungan antara variabel yang satu dengan variabel yang lain adalah searah, yang artinya apabila variabel yang satu meningkat maka variabel yang lain juga mengalami peningkatan. Tetapi apabila nilai korelasi negatif maka hubungan antara dua variabel berlawanan artinya apabila nilai variabel yang satu turun maka nilai variabel yang lain akan meningkat, atau sebaliknya.

Dari hasil analisi korelasi pada tabel diatas menunjukkan bahwa antara pertumbuhan ekonomi dengan indeks williamson memiliki hubungan negatif yang diperoleh nilai -0,333, yang artinya jika pertumbuhan ekonomi meningkat maka ketimpangannya turun. Hasil penelitian ini sesuai dengan penelitian yang dilakukan oleh Sutarno dan Kuncoro (2004) tentang pertumbuhan ekonomi dan ketimpangan antar kecamatan kasus kabupaten Banyumas Jawa Tengah. Hasil penelitian tersebut menunjukkan bahwa Kurva Kuznets tentang U terbalik berlaku di Kabupaten Banyumas artinya pada masa-masa awal pertumbuhan ketimpangan memburuk dan pada tahap-tahap berikutnya ketimpangan menurun, tetapi pada waktu tertentu akan terjadi peningkatan ketimpangan dan pada akhirnya mengalami penurun lagi sehingga dapat dikatakan peristiwa tersebut seperti berulang.

\section{SIMPULAN}

Berdasarkan hasil analisis data dan pembahasan penelitian diketahui bahwa; Hasil analisis tentang ketimpangan pem-
Timur

bangunan antar kabupaten/kota di Propinsi Kalimantan Timur tahun 2010-2012 dengan menggunakan Indeks Williamsom menunjukkan bahwa nilai Indeks Williamson mengalami peningkatan, yaitu pada tahun 2010 nilai indek williamson sebesar o,69, kemudian ditahun 2011 ketimpangan tidak mengalami peningkatan dan pada tahun 2012 ketimpangannya menigkat menjadi 0.72. Peningkatan ketimpangan pembangunan antar kabupaten/kota disebabkan oleh perbedaan kandungan sumber daya alam, perbedaan kondisi demografis, konsentrasi kegiatan ekonomi, dan alokasi dana pembangunan antar wilayah.

Ketimpangan pendapatan antar kabupaten/kota di Propinsi Kalimantan Timur tahun 2010-2012 dianalisis dengan menggunakan Indeks Entropy Theil. Hasil analisis menunjukkan bahwa nilai indeks entropi theil semakin kecil dengan kata lain distribusi pendapatan semakin merata dari tahun ketahun. Nilai indeks yang menurun semakin mendekati nol berarti distribusi pendapatan perkapita menurut kabupaten/kota di Propinsi Kalimantan Timur mulai merata. Namun, nilai indeks masih berada diatas o berarti kesenjangan pendapatan perkapita antar kabupaten/kota di Propinsi Kalimantan Timur menurut indikator yang ditetapkan oleh Bank Dunia masih belum menunjukkan tingkat kemerataan yang baik. Pada tahun 2010 (18.43) di tahun 2012 (16.99) dengan kata lain distribusi pendapatan di Kalimantan Timur selama tiga tahun terakhir semakin menurun, meskipun mengalami penurunan dari tahun ke tahun tetapi ketimpangan pendapatan di Kalimantan Timur masih jauh dari nol, sehingga dapat disimpulkan ketimpangannya sangat tinggi.

Hipotesis Kuznets tentang U-terbalik dianalisis dengan analisis Korelasi Pearson dalam menentukan korelasi (hubungan) antara pertumbuhan ekonomi dengan indeks Williamson. Hasil analisis adalah sebagai berikut : Berdasarkan hasil analisis korelasi(korelasi pearson) antara pertumbuhan ekonomi dan indeks Williamson, disimpulkan bahwa pertumbuhan ekonomi memiliki nilai korelasi negatif sebesar -0,333 artinya hubungan antara dua variabel 
berlawanan atau apabila pertumbuhan ekonomi meningkat maka ketimpangan pembangunan

\section{DAFTAR PUSTAKA}

Adelman, Irma., and Cynthia T.Morris. (1973). Economic Growth and Social Equity in Developing Countries. Stanford : Stanford University Press.

Adrei, Ana., and Liliana Craciun. (2014). Inequality and economic growth: theoretical and operational approach. Theoretical and Applied Economics Volume XXII (2015), No. 1(602), pp. 177-186.

Akita, T., \& Hermawan, A. (2000). The Sources of Industrial Growth in Indonesia, 1985-95: An Input Output Analysis. ASEAN Economic Bulletin,Vol. 17, No. 3.

Arsyad, Lincolin. (2004). Ekonomi Pembangunan (Edisi 4). Yogyakarta: STIE YKPN.

Barro, R.J. (1999). Inequality, Growth and Investment, Working Paper. National Bureau Of Economic Research Working Paper No. 7038.

Boediono. (1981). Teori Pertumbuhan Ekonomi. Edisi Pertama. Yogyakarta : BPFE

BPS. (2013). Kalimantan Timur Dalam Angka. Kalimantan Timur : BPS

Bratakusumah, Deddy S. (2003). Perencanaan Pembangunan Daerah : Strategi Menggali Potensi Dalam Mewujudkan Otonomi Daerah . Jakarta : PT. Gramedia Pustaka Utama.

Das, Samarjit. et al. (2014). Economic growth and income inequality: examining The links in indian economy. Journal of Quantitative Economics, Vol. 12, No.1, January 2014

Dewanto, Pendi. et al. (2014). Analisis pengaruh pertumbuhan ekonomi dan ketimpangan pendapatan terhadap Pengentasan kemiskinan di kawasan mebidangro. Jurnal Ekonom, Vol 17, No 3, Juli 2014

Fan, Cindy C. (1995). Of Belt And Ladders : State Policy And Uneven Regional Development In Post- Map China. Annals of the association of American geographer, vol.18 No. 3 PP. 421-449.

Galbraith, James K., and Hyunsub Kum. (2012). Inequality and Economic Growth: Data Comparisons and Econometric Tests. UTIP Working Paper Number 21

Garcia, F., dan Lilian Furquim L. (2001). A Contribution to the Empirics of Economic Growt. Journal of Development, Vol 27, No.9, 171-231.

Han, Taejoon. (2001). China : a Shared Poverty to Uneven Wealth?. The Georgia Washington University, Website http://www.gwu. edu/ econ270/taejoon.html. Diunduh pada tanggal 3 Maret 2015

Jhingan, M.L. (1999). Ekonomi Pembangunan dan Perencanaan (terjemahan). Edisi Ketujuh, Jakarta: PT. Raja Grafindo.

Kuncoro, Mudrajad. (2001). Analisis Spasial dan Regional. Yogyakarta : UPP AMP YKPN

Kuncoro, Mudrajad. (2004). Otonomi dan Pembangunan Daerah : Reformasi, Perencanaan, Strategi, dan Peluang. Jakarta : Erlangga

Kuznets, S. (1955). Economic Growth and Income Inequality. American Economic Review

Madani, R.A. (2005). Transformasi Struktural Dan Ketimpangan Antar Kabupaten/Kota Di Daerah Istimewa Yogyakarta. Tesis. Program Pascasarjana UGM, Yogyakarta.

Person, T., dan Tabellini T. (1994). Is Inequality Harmful For Growth. The American review. vol.84 No. 3 (Jun,1994). PP.6oo-621

Raswita, Ngakan Putu Mahesa Eka., dan Made Suyana Utama. (2013). Analisis Pertumbuhan Ekonomi dan Ketimpangan Pendapatan Antar Kecamatan Di Kabupaten Gianyar 2013. E-Jurnal EP Unud, 2 [3] : 119-128

Subagyo., dan Djarwanto. (2005). Statistika Induktif. Yogyakarta: BPFE Yogyakarta.

Sukirno, S. (1985). Ekonomi Pembangunan-Proses, Masalah dan Dasar Kebijakan. LP3ES-UI dengan Bina Grafika, Jakarta Sutarno, 2002. Pertumbuhan ekonomi dan ketimpangan PDRB Per kapita Antar Kecamatan di Kabupaten Banyumas 1993-2000. Tesis. Program Pasca sarjana UGM, Yogyakarta.

Sutarno., dan Mudrajad Kuncoro. (2004). Pertumbuhan Ekonomi dan Ketimpangan antar Kecamatan di Kabupaten Banyumas, 1993-2000. Jurnal Ekonomi Pembangunan

Syafrizal. (2008). Ekonomi Regional: Teori dan Aplikasi. Padang: Baduose Media.

Tambunan, Tulus. (2001). Perekonomian Indonesia: Beberapa Masalah Penting. Jakarta : Ghalia Indonesia Erlangga

Todaro, Michael P. (2003). Pembangunan Ekonomi Di Dunia Ketiga. Alih Bahasa: Aminuddin dan Drs.Mursid. Jakarta: Ghalia Indonesia

Todaro, Michael P. (2004). Pembangunan Ekonomi Di Dunia Ketiga. Edisi Kedelapan. Jakarta: Erlangga.

Wei, Y Dennis., dan Fan C Cindy. (200o). Regional Inequality in China : a Case Study of Jiangsu Province. Asian Economic Journal. Vol. 52, 455-469.

Yin, Robert K. (2000). Studi Kasus (Desain dan Metode). Jakarta: PT. Raja Grafindo Persada. 